\title{
Direct Effect of Silicon and Sulphur on Nutrient Content and Uptake of Rice Crop under Rice-Wheat Cropping Sequence
}

\author{
Vimal N. Patel*, K.C. Patel and K.V. Chaudhary \\ Department of Soil Science and Agricultural Chemistry, B. A. College of Agriculture, \\ Anand Agricultural University, Anand, Gujarat, India \\ *Corresponding author
}

A B S T R A C T

The field experiment was conducted on "Effect of silicon and sulphur on yield and chemical composition on rice and its residual effect on wheat in loamy sand soil" during

\begin{tabular}{|l|}
\hline Key w or d s \\
Silicon, Sulphur, \\
Rice, Phosphorus, \\
Content, Uptake \\
\hline Article Info \\
\hline Accepted: \\
07 March 2019 \\
Available Online: \\
10 April 2019 \\
\hline \hline
\end{tabular}
the kharif and rabi seasons for two years 2016-17 and 2017-18 at Regional Research Station farm, Anand Agricultural University, Anand (Gujarat). The experiment was laid out in Randomized Block Design with factorial concept, comprising twelve treatment combinations of four levels of silicon $\left(0,150,300\right.$ and $\left.450 \mathrm{~kg} \mathrm{Si} \mathrm{ha}^{-1}\right)$ and three levels of sulphur $\left(0,20\right.$ and $\left.40 \mathrm{~kg} \mathrm{~S}^{-1}\right)$ with three replications. The maximum Si and S content in grain and straw was noticed due to combined application of $450 \mathrm{~kg} \mathrm{Si} \mathrm{ha}^{-1}$ and $40 \mathrm{~kg} \mathrm{~S}^{-}$ 1 . Significantly higher phosphorus content in grain and straw was found under application of $450 \mathrm{~kg} \mathrm{Si} \mathrm{ha}^{-1}$.No significant change in P content in grain and straw were observed with varying levels of $\mathrm{S}$ application. Significantly highest $\mathrm{Si}$ and $\mathrm{S}$ uptake by rice grain and straw was observed under highest $\mathrm{Si}$ application $\left(450 \mathrm{~kg} \mathrm{Si} \mathrm{ha}^{-1}\right)$ with highest $\mathrm{S}$ level at 40 $\mathrm{kg} \mathrm{ha}^{-1}$ over rest of the combinations. The maximum $\mathrm{P}$ uptake by rice grain and in rice straw was recorded due to application of $450 \mathrm{~kg} \mathrm{Si} \mathrm{ha}^{-1}$ during both the years as well as on pooled basis respectively. Addition of sulphur increased $\mathrm{P}$ uptake by grain and the maximum uptake was recorded at $40 \mathrm{~kg} \mathrm{~S}^{-1}$ during second year and pooled basis.

\section{Introduction}

Silicon content in different parts of a rice plant generally ranged from high to low, in descending rank in the hull, leaf, leaf sheath, culm, and root (Zhu, 1985). Silicon helps plants to overcome multiple stresses including biotic and abiotic stresses (Ma, 2004). For example, $\mathrm{Si}$ plays an important role in increasing the resistance of plants to pathogens such as blast on rice (Datnoff et al., 1997) and also alleviates the effects of other abiotic stresses including salt stress, metal toxicity, drought stress, radiation damage, nutrient imbalance, high temperature, and freezing (Ma and Takahashi, 2002). In crop production the benefits from $\mathrm{Si}$ fertilization may include increased yield, disease and insect resistance and tolerance to stresses such as cold, drought, and toxic metals. Rice, wheat, cucurbits, corn and sugarcane are crops that have been shown to benefit from $\mathrm{Si}$ fertilization. In addition to crops, the value of silicon is gaining attention in animal nutrition 
where Si may play a role in the health of bone, joints, skin, hair and connective tissues. $\mathrm{Si}$ exists in all plants grown in soil and its content in plant tissue ranges from 0.1 to $10 \%$.

Sulphur (S) is one of the sixteen essential plant nutrients and ranks fourth major nutrient next to $\mathrm{N}, \mathrm{P}$ and $\mathrm{K}$. Crop requires sulphur generally as much phosphorus and one tenth of nitrogen. Among the essential elements, sulphur is very much beneficial for increasing the production of rice and is one of the major essential nutrient elements involved in the synthesis of chlorophyll, certain amino acids like methionine, cystine, cysteine and some plant hormones such as thiamine and biotin (Rahman et al., 2007). Accumulation of inorganic nitrogen or organic non-protein nitrogen in the tissue, leaf area, seed number plant $^{-1}$, floral initiation and anthesis in plants are affected by the presence or absence of sulphur (Tiwari, 1994). Growing of sulphur responsive crops, high intensive cropping and use of sulphur free fertilizers caused $S$ deficiency in soils of India (Tandon and Tiwari, 2007).

Paddy is considered as silicon accumulator. An adequate supply of silicon to paddy from tillering to elongation stage increases the number of grains per panicle and enhances ripening (Korndorfer et al., 2001). It is also suggested that the silicon plays a crucial role in preventing or minimizing the lodging incidence in the cereal crops, a matter of great importance in terms of crop productivity. Rice is the staple food of about half of the world's population. The benefits from Si fertilization may include increased yield, enhanced disease and insect resistance and tolerance to stresses such as cold, drought and toxic metals. Various crops like wheat, cucurbits, corn and sugarcane have been shown to be benefited from Si fertilization.

\section{Materials and Methods}

The field experiment was conducted during the kharif season for two years 2016-17 and 2017-18 at the Regional Research Station, Anand Agricultural University, Anand, Gujarat. The soil of the experimental field was loamy sand in texture with the $\mathrm{pH}$ of 7.8 and organic carbon $0.30 \%$. The soluble salts (EC) content was medium and an overall mean value of $0.23 \mathrm{dS} \mathrm{m} \mathrm{m}^{-1}$.The status of available nutrients like $\mathrm{Si}\left(68.73 \mathrm{mg} \mathrm{kg}^{-1}\right)$, $\mathrm{P}_{2} \mathrm{O}_{5}$ (32.58 kg ha $\left.{ }^{-1}\right), \mathrm{S}\left(9.81 \mathrm{mg} \mathrm{kg}^{-1}\right), \mathrm{Fe}$ (7.31 mg kg-1) and $\mathrm{Zn}\left(1.23 \mathrm{mg} \mathrm{kg}^{-1}\right)$. The treatment comprised of four levels of silicon (Si) $\left(0,150,300\right.$ and $450 \mathrm{~kg} \mathrm{ha}^{-1}$ through calcium silicate) and three levels of sulphur (S) $\left(0,20\right.$ and $40 \mathrm{~kg} \mathrm{ha}^{-1}$ through bentonite sulphur) were applied as basal along with recommended NPK dose of fertilizers (120: 40: $\left.00 \mathrm{~kg} \mathrm{ha}^{-1}\right)$. The experiment was laid out in factorial randomized block design with three replications. Available silicon in the soils was extracted by using NaOAc (14.8 $\mathrm{g}$ $\mathrm{NaOAc}+49.2 \mathrm{~mL}$ acetic acid $\mathrm{L}^{-1}$, adjusted to $\mathrm{pH}$ 4, Sample: solution=10 g: $100 \mathrm{ml}, 1 \mathrm{hr}$. shaking) and silicon in the extracting solution was determined by taking $1 \mathrm{ml}$ of aliquot from filtrate into plastic centrifuge tube, 30 $\mathrm{mL}$ of acetic acid and $10 \mathrm{~mL}$ of ammonium molybdate solution (54 $\mathrm{g} \mathrm{L}^{-1} \mathrm{pH} 7$ ) and then after 5 minutes, $5 \mathrm{~mL}$ of $20 \%$ tartaric acid solution and after two minutes, $1 \mathrm{~mL}$ reducing agent ANSA (1-amino-2- naphthol-4sulphonic acid) were added and final volume was made upto $50 \mathrm{~mL}$ with $20 \%$ acetic acid. Within thirty minutes, concentration of silicon was measured as absorbance at $650 \mathrm{~nm}$ on UV, Visible Spectrophotometer (Korndorfer et al., 1999).

For the plant samples the powered sample $(0.1 \mathrm{~g})$ was digested in a mixture of $2 \mathrm{~mL}$ of $50 \% \mathrm{H}_{2} \mathrm{O}_{2}$ and then $4.5 \mathrm{~mL}$ of $50 \% \mathrm{NaOH}$ was added at ambient temperature in each polypropylene $100 \mathrm{~mL}$ tube. The tubes were 
individually covered with loose fitting plastic cups. The rack of tubes was placed in an autoclave (15 psi \& $138 \mathrm{Kpa}$ ) for one hour. The volume of digested contents in the tubes was made up to $50 \mathrm{~mL}$ with double distilled water and after filtration; $1 \mathrm{~mL}$ aliquot was taken for Si estimation (Dai et al., 2005). The $\mathrm{Si}$ concentration in the digested solution was determined by $1 \mathrm{~mL}$ of digested aliquot. It was transferred to a plastic centrifuge tube and $30 \mathrm{~mL}$ of $20 \%$ acetic acid, $10 \mathrm{~mL}$ of ammonium molybdate (54 $\left.\mathrm{g} \mathrm{L}^{1} \mathrm{pH} 7\right), 5 \mathrm{~mL}$ of $20 \%$ tartaric acid and $1 \mathrm{~mL}$ of reducing ANSA solution (1-amino-2- naphthol-4sulphonic acid) were added and the volume was made up to $50 \mathrm{~mL}$ with $20 \%$ acetic acid. After 30 minutes, the absorbance was measured at $650 \mathrm{~nm}$ on UV, Visible Spectrophotometer (Dai et al., 2005). Similarly, $100 \mathrm{ppm} \mathrm{SiO}_{2}$ strength and a stock solution of $\mathrm{Si}$ standards (0, 0.2, 0.4, 0.8 and $1.2 \mathrm{ppm}$ ) were prepared by following the same procedure and silicon concentration was measured on spectrophotometer to find out the graph factor from a standard curve by plotting $\mathrm{Si}$ concentration on $\mathrm{X}$ axis and optical density on the $\mathrm{Y}$ axis. Nutrient uptake by both grain and straw of rice and wheat was calculated using the values of nutrient content and yield of grain and straw $\left(\mathrm{kg} \mathrm{ha}^{-1}\right)$. The experimental data were analyzed as per the procedure outlined by Steel and Torrie (1982).

\section{Results and Discussion}

The application of Si significantly affected $\mathrm{Si}$ content in grain of rice. Significantly highest average silicon content in grain $(2.22 \%)$ was found under application of $450 \mathrm{~kg} \mathrm{Si} \mathrm{ha}^{-1}$ over rest of the treatments. Application of $40 \mathrm{~kg} \mathrm{~S}$ $\mathrm{ha}^{-1}$ significantly increased the average $\mathrm{Si}$ content in grain $(1.79 \%)$. The maximum $\mathrm{Si}$ content in grain was noticed due to combined application of $450 \mathrm{~kg} \mathrm{Si} \mathrm{ha}{ }^{-1}$ and $40 \mathrm{~kg} \mathrm{~S} \mathrm{ha}^{-1}$ (Table 1). Significantly highest average silicon content in straw $(6.78 \%)$ was found under application of $450 \mathrm{~kg} \mathrm{Si} \mathrm{ha}{ }^{-1}$ over rest of the treatments. Application of $40 \mathrm{~kg} \mathrm{~S}^{-1}$ significantly increased the average $\mathrm{Si}$ content in straw $(5.67 \%)$. The maximum $\mathrm{Si}$ content in straw was noticed due to combined application of $450 \mathrm{~kg} \mathrm{Si} \mathrm{ha}^{-1}$ and $40 \mathrm{~kg} \mathrm{~S} \mathrm{ha}^{-1}$ (Table 2). The nutrients content in rice significantly affected by silicon and sulphur application and similar results also obtained by Deren et al., (1994) and marked that increase in $\mathrm{Si}$ concentration in plant tissue with increasing rate of $\mathrm{Si}$ fertilization and cultivars differed for $\mathrm{Si}$ concentration and its uptake, thus, stressed the necessity for identifying or developing rice genotypes which are more efficient in accumulating available $\mathrm{Si}$ which may be of particular benefit on $\mathrm{Si}$ deficient soils. Hayasaka et al., (2005) reported that the response of rice plants to $\mathrm{Si}$ fertilization depends on soil factors such as Si availability to the plant and on plant factors such as the Si content of plant tissues. The amount of available $\mathrm{Si}$ in soils varies with soil composition. Thus, the $\mathrm{Si}$ content depends on the kind of soil used. In their study, application of silica gel effectively increased the Si content of nursery seedlings regardless of soil type. The results are in agreement with the findings of Islam and Saha (1969); Inanaga et al., (2002); Shivay and Dinesh Kumar (2009) and Idris et al., (1975).

The maximum average $\mathrm{S}$ content in grain $(0.172 \%)$ was noticed at maximum level of $\mathrm{Si}$ application. The maximum increment over control was to the tune of 39.83 per cent higher on a pooled basis. Among the various $\mathrm{S}$ levels, application of $40 \mathrm{~kg} \mathrm{~S} \mathrm{ha}^{-1}$ produced significantly higher average $S$ content in grain $(0.164 \%)$. The maximum increment over control was to the tune of 33.35 per cent higher on pooled basis. The highest $\mathrm{S}$ content in grain was noticed due to combined effect of $450 \mathrm{~kg} \mathrm{Si} \mathrm{ha}^{-1}$ and $40 \mathrm{~kg} \mathrm{~S}^{-1}$ application 
(Table 1). The maximum average $\mathrm{S}$ content in straw $(0.123 \%)$ was noticed at maximum level of $\mathrm{Si}$ application. The maximum increment over control was to the tune of 38.20 per cent higher on a pooled basis. Among the various $\mathrm{S}$ levels, application of 40 $\mathrm{kg} \mathrm{S} \mathrm{ha}^{-1}$ produced significantly higher average $\mathrm{S}$ content in straw $(0.129 \%)$. The maximum increment over control was to the tune of 67.46 per cent higher on pooled basis. The highest $\mathrm{S}$ content in straw was noticed due to combined effect of $450 \mathrm{~kg} \mathrm{Si} \mathrm{ha}{ }^{-1}$ and $40 \mathrm{~kg} \mathrm{~S} \mathrm{ha}^{-1}$ application (Table 2). Increase in Si levels ultimately increased the absorption of sulphur and $\mathrm{CO}_{2}$ thus it blocks the hatches and improve the photosynthesis (Gerami et al., 2012). Tiwari et al., (1983) and Hoque and Eaqub (1984) reported that sulphur application increased its content in grain and straw. The findings of the present study are in conformity with the results reported by Mandata et al., (1994) who noted that concentration of $\mathrm{Si}$ in rice plant increased with increasing rates of $\mathrm{S}$ application. Islam $e t$ al., (1987) reported that the highest $\mathrm{S}$ content in plant was noted when 30 to $40 \mathrm{~kg} \mathrm{~S}^{-1}$ were added to the soil. The increased in sulphur content of straw by $\mathrm{Si}$ application might be due to greater availability of this nutrient. Malidareh et al., (2009) reported that sulphur content in rice straw increased with increasing $\mathrm{Si}$ application

Significantly higher phosphorus content in grain was found under application of $450 \mathrm{~kg}$ $\mathrm{Si} \mathrm{ha}^{-1}$.The $\mathrm{P}$ content in grain was increased from 0.194 to $0.249 \%, 0.198$ to $0.253 \%$ and 0.196 to $0.251 \%$ during both the years as well as on pooled basis, respectively (Table 1). Significantly higher phosphorus content in straw was found under application of $450 \mathrm{~kg}$ $\mathrm{Si} \mathrm{ha}{ }^{-1}$. The $\mathrm{P}$ content in straw was increased from 0.076 to $0.106 \%, 0.071$ to $0.115 \%$ and 0.073 to $0.112 \%$ during both the years as well as on pooled basis, respectively. No significant change in $\mathrm{P}$ content in grain and straw were observed with varying levels of $S$ application (Table 2). Owino and Gascho (2004) indicated that the P content increased when $\mathrm{Si}$ was applied, which could be attributed to the increase in the soil $\mathrm{pH}$ from the accompanying $\mathrm{Ca}$ and $\mathrm{Si}$ concentration in the soil solution, which improved the conditions for uptake of P by maize. Similar results were also recorded by $\mathrm{Ma}$ and Takahashi (2002) and Hellal et al., (2012). Increased $\mathrm{P}$ in grain and straw could be attributed to enhanced translocation of $\mathrm{P}$ from roots to shoots due to Si application (Wang et al., 2001). Sauer and Burghardt (2000) also opined that when $\mathrm{P}$ is not applied, $\mathrm{Si}$ fertilization increased the $\mathrm{P}$ content of rice straw and grain which could be attributed to better availability of native soil $\mathrm{P}$ and enhanced mobility of $\mathrm{P}$ from the roots to the stem. The beneficial effect of $\mathrm{Si}$ when available $\mathrm{P}$ is low can be explained as a partial substitution of $\mathrm{Si}$ for $\mathrm{P}(\mathrm{Ma}$ and Takahashi 1990). In the absence of $\mathrm{Si}$, a considerable decrease in the incorporation of inorganic phosphates into ATP and ADP and sugar phosphate has been observed in sugar cane (Wong You Cheong et al., 1973).

The application of $\mathrm{Si}\left(450 \mathrm{~kg} \mathrm{ha}^{-1}\right)$ resulted in maximum $\mathrm{Si}$ uptake by rice grain $(139.58 \mathrm{~kg}$ $\left.\mathrm{ha}^{-1}\right)$. The $\mathrm{Si}$ uptake by rice grain was observed significantly highest at $\mathrm{S}_{40}$ level as compared to $\mathrm{S}_{20}$ and $\mathrm{S}_{0}$ levels. The values were ranged from 88.71 to $112.47 \mathrm{~kg} \mathrm{ha}^{-1}$. Significantly highest $\mathrm{Si}$ uptake in rice grain was observed under highest $\mathrm{Si}$ application $\left(450 \mathrm{~kg} \mathrm{Si} \mathrm{ha}{ }^{-1}\right)$ with highest $\mathrm{S}$ level at $40 \mathrm{~kg}$ $\mathrm{ha}^{-1}\left(174.32 \mathrm{~kg} \mathrm{ha}{ }^{-1}\right)$ over rest of the combinations (Table 3 ).

Significantly highest $\mathrm{Si}$ uptake by straw was noticed due to application of $450 \mathrm{~kg} \mathrm{Si} \mathrm{ha}{ }^{-1}$. The value was in range of 292.08 to 536.12 , 324.26 to 564.49 and 308.17 to $550.39 \mathrm{~kg} \mathrm{ha}^{-1}$ during both the years as well as on pooled basis respectively, over control. 
Table.1 Effect of silicon and sulphur on silicon, sulphur and phosphorus content of rice grain under rice - wheat cropping sequence

\begin{tabular}{|c|c|c|c|c|c|c|c|c|c|}
\hline & \multicolumn{3}{|c|}{ Silicon content $(\%)$ in grain } & \multicolumn{3}{|c|}{ Sulphur content $(\%)$ in grain } & \multicolumn{3}{|c|}{ Phosphorus content $(\%)$ in grain } \\
\hline Treatment & 2016-17 & 2017-18 & Pooled & 2016-17 & 2017-18 & Pooled & 2016-17 & 2017-18 & Pooled \\
\hline \multicolumn{10}{|c|}{ Silicon levels (kg ha $\left.{ }^{-1}\right)$} \\
\hline $\mathbf{S i}_{0}$ & 1.12 & 1.23 & 1.18 & 0.120 & 0.127 & 0.123 & 0.194 & 0.198 & 0.196 \\
\hline $\mathbf{S i}_{150}$ & 1.35 & 1.46 & 1.41 & 0.137 & 0.143 & 0.140 & 0.215 & 0.215 & 0.215 \\
\hline $\mathrm{Si}_{300}$ & 1.87 & 1.99 & 1.93 & 0.153 & 0.162 & 0.157 & 0.232 & 0.237 & 0.134 \\
\hline $\mathrm{Si}_{450}$ & 2.16 & 2.27 & 2.22 & 0.169 & 0.175 & 0.172 & 0.249 & 0.253 & 0.251 \\
\hline S.Em. \pm & 0.05 & 0.06 & 0.04 & 0.004 & 0.003 & 0.003 & 0.007 & 0.005 & 0.004 \\
\hline $\begin{array}{c}\text { CD } \\
(P=0.05)\end{array}$ & 0.14 & 0.18 & 0.11 & 0.011 & 0.009 & 0.008 & 0.020 & 0.016 & 0.011 \\
\hline \multicolumn{10}{|c|}{ Sulphur levels $\left(\mathrm{kg} \mathrm{ha}^{-1}\right)$} \\
\hline$S_{0}$ & 1.54 & 1.59 & 1.56 & 0.120 & 0.125 & 0.123 & 0.217 & 0.219 & 0.218 \\
\hline $\mathbf{S}_{20}$ & 1.64 & 1.73 & 1.69 & 0.154 & 0.161 & 0.158 & 0.223 & 0.226 & 0.225 \\
\hline$S_{40}$ & 1.71 & 1.88 & 1.79 & 0.161 & 0.168 & 0.164 & 0.227 & 0.231 & 0.229 \\
\hline S.Em. \pm & 0.04 & 0.05 & 0.03 & 0.003 & 0.003 & 0.002 & 0.006 & 0.005 & 0.003 \\
\hline $\begin{array}{c}\text { CD } \\
(\mathbf{P}=0.05)\end{array}$ & 0.12 & 0.16 & 0.10 & 0.009 & 0.008 & 0.007 & NS & NS & NS \\
\hline $\begin{array}{l}\text { Significant } \\
\text { interactions }\end{array}$ & $\mathrm{Si} \times \mathrm{S}$ & $\mathrm{Si} \times \mathrm{S}$ & $\mathrm{Si} \times \mathrm{S}$ & $\mathrm{Si} \times \mathrm{S}$ & $\mathrm{Si} \times \mathrm{S}$ & $\mathrm{Si} \times \mathrm{S}$ & - & - & - \\
\hline CV \% & 8.59 & 10.80 & 8.51 & 7.75 & 6.04 & 5.51 & 9.25 & 7.24 & 9.55 \\
\hline
\end{tabular}

Table.2 Effect of silicon and sulphur on silicon, sulphur and phosphorus content of rice straw under rice - wheat cropping sequence

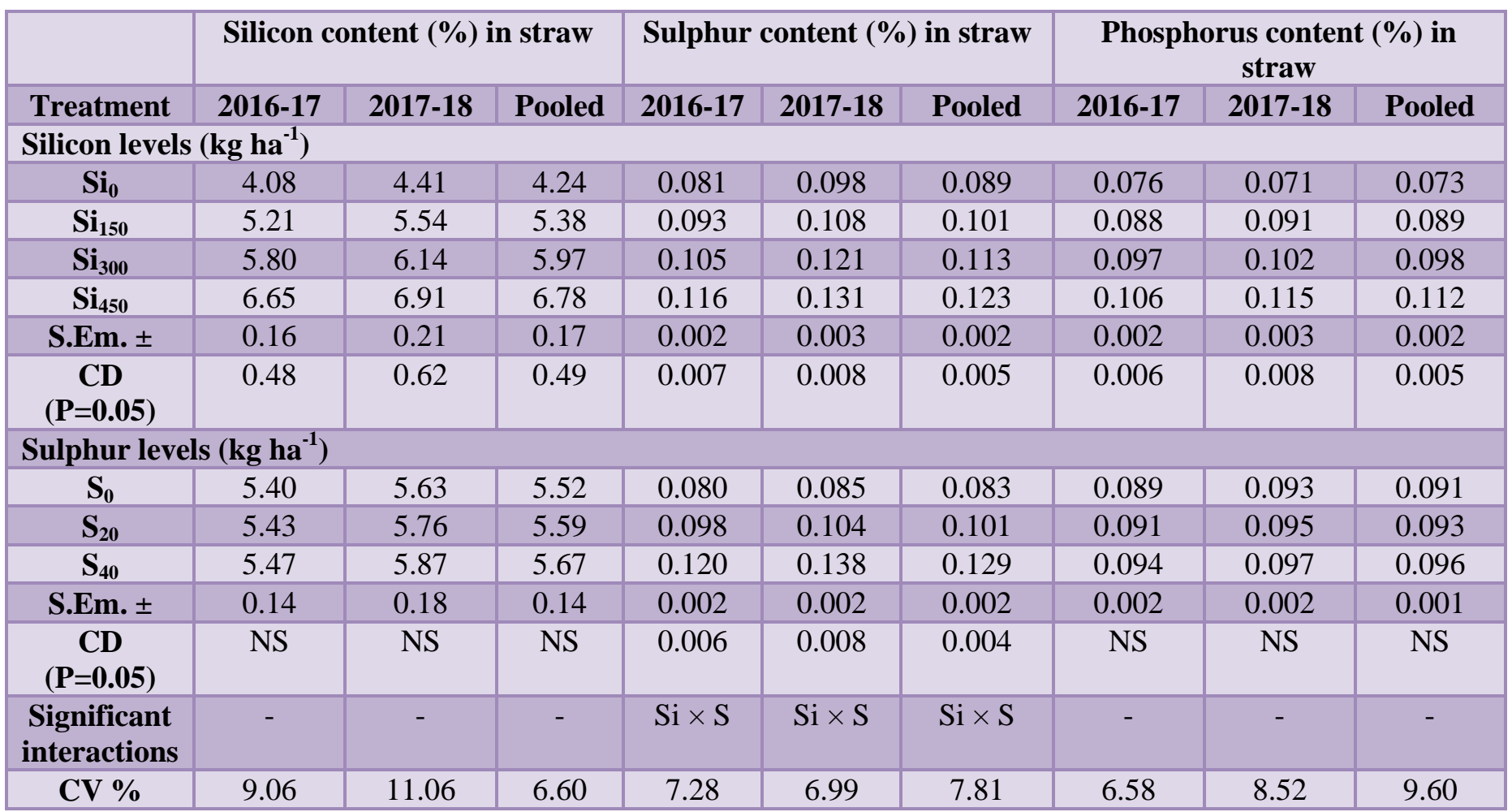


Table.3 Effect of silicon and sulphur on silicon, sulphur and phosphorus uptake by rice grain under rice - wheat cropping sequence

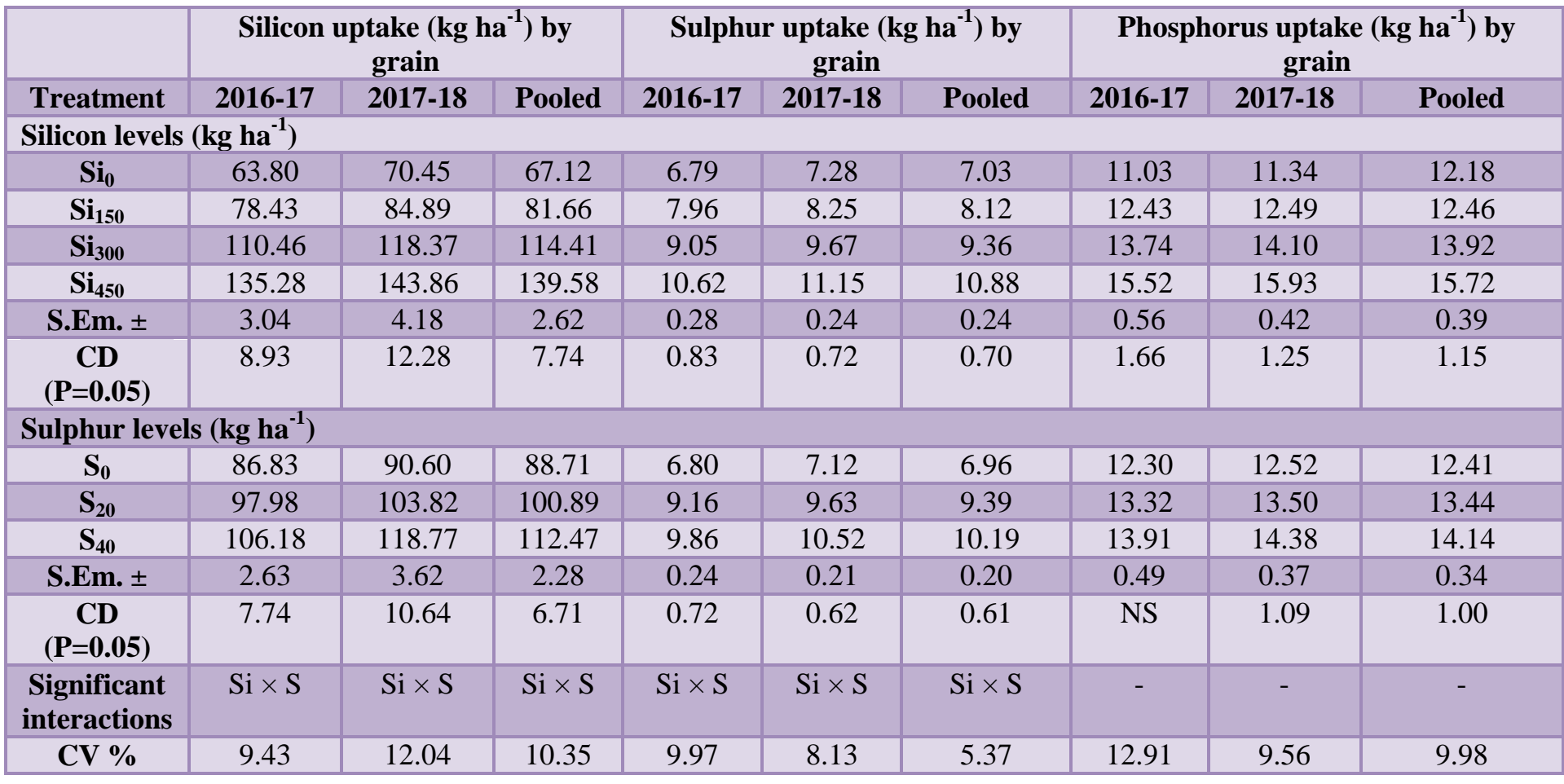

Table.4 Effect of silicon and sulphur on silicon, sulphur and phosphorus uptake by rice straw under rice - wheat cropping sequence

\begin{tabular}{|c|c|c|c|c|c|c|c|c|c|c|}
\hline & \multicolumn{3}{|c|}{ Silicon uptake(kg ha } \\
\hline
\end{tabular}


The Si uptake by rice straw was higher with $40 \mathrm{~kg} \mathrm{~S} \mathrm{ha}^{-1}$ compared to $20 \mathrm{~kg} \mathrm{~S} \mathrm{ha}^{-1}$ and $0 \mathrm{~kg}$ $\mathrm{S} \mathrm{ha}^{-1}$ levels (Table 4). The silicon uptake is mainly dependent on Si supplying ability of the soil and with increased application of $\mathrm{Si}$, there was increase in solubilisation of $\mathrm{Si}$ and thus Si uptake. These results are in agreement with the findings of Sumida (1992); Singh et al., (2006); Osuna et al., (1991) and Korndorfer et al., (2001). This could be also due to increased root activity and enhanced soil nutrient availability. This is in accordance with the reports of Wani et al., (2000). Further, the increased uptake with crop growth might be attributed to the increased DMP produced with growth of crop due to the enhanced release and consequent availability of nutrients to the crops. The silicon uptake was higher in straw compared to the uptake by grain at harvest. Ma and Takahashi (2002) reported that beneficial effects of $\mathrm{Si}$ exposed through silicon deposition in the leaves, stems and hulls. Therefore silicon is characterized by wide effects associated with greater $\mathrm{Si}$ accumulation in the shoots. Ma and Yamaji (2006) explained that the variation in the uptake values by the two verities could be due to differential expression of gene, which belongs to the Aquaporin family and is constitutively expressed in the roots. It is localized on the plasma membrane of the distal side of both exodermis and endodermis cells, where casparin strips are located.

Significantly higher $\mathrm{S}$ uptake by grain (10.88 $\mathrm{kg} \mathrm{ha}^{-1}$ ) was observed under Si application@ $450 \mathrm{~kg} \mathrm{Si} \mathrm{ha}{ }^{-1}$. Maximum $\mathrm{S}$ uptake by grain $\left(10.19 \mathrm{~kg} \mathrm{ha}^{-1}\right)$ was recorded at maximum level of $\mathrm{S}$ application. Significantly highest $\mathrm{S}$ uptake by rice grain was observed under highest $\mathrm{Si}$ application (450 $\mathrm{kg} \mathrm{Si} \mathrm{ha}{ }^{-1}$ ) with highest $\mathrm{S}$ level at $40 \mathrm{~kg} \mathrm{ha}^{-1}\left(13.43 \mathrm{~kg} \mathrm{ha}^{-1}\right)$ over rest of the combinations (Table 3). Significantly higher S uptake straw $(10.18 \mathrm{~kg}$ $\mathrm{ha}^{-1}$ ) was observed under Si application @ $450 \mathrm{~kg} \mathrm{Si} \mathrm{ha}{ }^{-1}$. Maximum S uptake by straw
(11.13 $\mathrm{kg} \mathrm{ha}^{-1}$ ) was recorded at maximum level of $\mathrm{S}$ application. Significantly highest $\mathrm{S}$ uptake by rice straw was observed under highest $\mathrm{Si}$ application (450 kg Si ha ${ }^{-1}$ ) with highest $\mathrm{S}$ level at $40 \mathrm{~kg} \mathrm{ha}^{-1}\left(14.39 \mathrm{~kg} \mathrm{ha}^{-1}\right)$ over rest of the combinations (Table 4). Silicon also favorably influenced the sulphur uptake showing its synergistic effect with silicon application as reported by Jawahar and Vaiyapuri (2010).The silicon fertilization significantly increased $S$ uptake by grain due to increased availability of $\mathrm{S}$ in soil. These results are in agreement with the findings of Sumida (1992); Singh et al., (2006); Osuna et al., (1991) and Korndorfer et al., (2001).Significant increase in S uptake within $S$ levels could be due to increased availability of $S$ in the soil from applied $S$ with concomitant increase in grain yield. Vaiyapuri and Sriramachandrasekharan (2001) had reported increase in sulphur uptake by rice with increase in $\mathrm{S}$ levels earlier.

The maximum $\mathrm{P}$ uptake by rice grain (15.52, 15.92 and $15.72 \mathrm{~kg} \mathrm{ha}^{-1}$ ) was recorded due to application of $450 \mathrm{~kg} \mathrm{Si} \mathrm{ha}{ }^{-1}$ during both the years as well as on pooled basis respectively. Addition of sulphur increased $\mathrm{P}$ uptake by grain and the maximum uptake was recorded at $40 \mathrm{~kg} \mathrm{~S} \mathrm{ha}^{-1}$ during second year and pooled basis however, effect of sulphur was nonsignificant in first year. The maximum improvement was to the value of 13.94 per cent higher during pooled basis over control (Table 3). The maximum $\mathrm{P}$ uptake by rice straw (8.51, 9.45 and $8.94 \mathrm{~kg} \mathrm{ha}^{-1}$ ) was recorded due to application of $450 \mathrm{~kg} \mathrm{Si} \mathrm{ha}^{-1}$ during both the years as well as on pooled basis respectively. The $\mathrm{P}$ uptake in rice straw was higher with $S_{40}$ compared to $S_{20}$ and $S_{0}$ levels; however, it was at par with $20 \mathrm{~kg} \mathrm{~S}^{-}$ 1 during first year. The maximum improvement was to the value of 15.93 per cent higher during pooled basis over control (Table 4). Increasing silicon levels increased phosphorus content due to decreased retention 
capacity of soil and increased solubility of phosphorus leading to increased efficiency of phosphatic fertilizer (Subramanian and Gopalswamy, 1991). These results are in line with Chanchareonsook et al., (2002) who reported that application NPK fertilizer in combination with $\mathrm{Si}$ significantly increased total N, P and $\mathrm{K}$ uptake of rice. The increased in $\mathrm{P}$ uptake by silicon application might be due to increase in soil available $\mathrm{P}$ as both of these nutrients are absorbed by plants. Phosphorus use efficiency is enhanced by silicon application and the beneficial effect of silicon is seen when available $\mathrm{P}$ is low it may due to partial substituting of silicon for $\mathrm{P}$ or an improvement of $\mathrm{P}$ availability in soil. On mineral soils with low soil $\mathrm{pH}$, phosphorus present as complex with $\mathrm{Al}$ and $\mathrm{Fe}$ phosphate may become plant available with addition of silicon thereby increasing crop yield. Presence of silicon increased phosphorus concentration and $\mathrm{P}$ uptake due to enhanced phosphate absorption and it was attributed to the availability of silicate ions to displace the fixed phosphorus ions in the soil leading to increased phosphorus uptake. Depressing effect of silicate on $\mathrm{P}$ retention capacity of soil may be added reasons to increase the level of water soluble $\mathrm{P}$ in the soil. Hence, it can be inferred that the increase in the uptake of $\mathrm{P}$ with the application of silicon might be attributed to enhanced availability and uptake of nutrients from soil which is made possible by desorption of $\mathrm{P}$ (Subramaniyan and Gopalaswarmy, 1991). Higher P uptake in the presence of $S$ could be due to the capacity of $\mathrm{S}$ in mobilizing soil $\mathrm{P}$ into available form. Muneshwar Singh et al., (2001) reported that $\mathrm{P}$ and $\mathrm{K}$ uptake were stimulated in the presence of $\mathrm{S}$.

In conclusion, application of silicon @ $450 \mathrm{~kg}$ $\mathrm{ha}^{-1}$ and sulphur @40 kg ha ${ }^{-1}$ recorded maximum $\mathrm{Si}, \mathrm{P}$ and $\mathrm{S}$ content and uptake by rice in loamy sand soil under rice - wheat cropping sequence.

\section{References}

Chanchareonsook, J., Suwannarat, C., Thongpae, S., Chanchareonsook, S. and Thinai, P. (2002). Bioremediation of rice grown acid soils through acid tolerant cyanobacteria. In Proceedings of the 17th World Congress Soil Science, 14-21 August 2002, International Union of Soil Sciences, Bangkok, Thailand. 377.

Datnoff, L. E., Deren, C. W. and Snyder, G. H. (1997). Silicon fertilization for disease management of rice in Florida. Crop Protection, 16, 525-531.

Deren, C. W., Datnoff, L. E. Snyder, G. H. and Martin, F. G. (1994). Silicon content, disease response and components of yield of rice genotypes grown on flooded organic Histosols. Crop Sciences, 34, 733 - 737.

Gerami, M., Fallah, A. and Moghadam, M.K. (2012). Study of potassium and sodium silicate on the morphological and chlorophyll content on the rice plant in pot experiment (Oryza sativa L.). International Journal of Agriculture and Crop Sciences, 4, 658-661.

Hayasaka, T., Fuji, H. and Namai, T. (2005). Silicon content in rice seedlings to protect rice blast fungus at the nursery stage. Journal of General Plant Pathology71, 169-173.

Hellal, F. A., Zeveny, R. M. and Yassen, A. A. (2012). Evaluation of nitrogen and silicon application for enhancing yield production and nutrient uptake by wheat in clay soil. Journal of Applied Sciences Research, 8 (2), 686-692.

Hoque, M. S. and Eaqub, M. (1984). Study on zinc and sulphur deficiency in Bangladesh Soils. Annual Report, FAO(Food \& Agriculture Org.) Project (1983-84).

Idris, M.D., Hossain, M.H. and Choudhary, 
F.A. (1975). The effect of silicon on lodging of rice in presence of added nitrogen. Plant and Soil, 43, 691-695.

Inanaga, S., Higues, Y. and Naoya, C. (2002). Effect of silicon application on reproductive growth of rice plant. Soil Science and Plant Nutrition, 48, 341347.

Islam, A. and Saha, R.C. (1969). Effect of silicon on the chemical composition of rice plant. Plant and Soil,30(3), 446 457.

Islam, R., Hossain, M. S. A., Howladar, A. S., Islam, A. R. and Haq, S.M.I. (1987). Effect of $\mathrm{S}$ on rice under flooded conduction. International Journal of Tropical Agriculture, 5 (2), 93-101.

Jawahar, S. and Vaiyapuri, V. (2010). Effect of sulphur and silicon fertilization on growth and yield of rice. International Journal of Current Research Vol. 9, pp.036-038,

Korndorfer, G.H., Snyder, G.H., Ulloa, M. and Datnoff, L.E. (2001). Calibration of soil and plant silicon for rice production. Journal of Plant Nutrition, 24, 1071-1084.

Ma, J. F. (2004). Role of silicon in enhancing the resistance of plants to biotic abiotic stresses. Soil Science and Plant Nutrition, 50, 11-18

Ma, J.F. and Takahashi, E. (1990). Effect of silicate on phosphate availability of rice in a $\mathrm{P}$ deficient soil. Plant and Soil, 133, 151-155.

Ma, J.F. and Takahashi, E. (2002). Soil, fertilizer, and plant silicon research in Japan. Elsevier Science, Amsterdam, The Netherlands.

Ma, J.F. and Yamaji, N. (2006). Silicon uptake and accumulation in higher plants. Trends in Plant Science, 11, 392-397.

Malidareh, G.A., Kashani, A., Nournohammadi, H.R., Mobasser. and Atavi, V. (2009). Effect of silicon application and nitrogen rates on $\mathrm{N}$ and Si content and yield of rice (Oryza sativa L.) in two water systems in north of Iran. World Applied Sciences Journal, 6(6), 719-727.

Mandata, S., Singh, R. P., Singh, B and Singh, M. (1994). Influence of $S$ application of N. P and S content of plant and soil. Crop Res., Hisar. 7 (1), 8-12.

Muneshwar Singh., V.P.Singh and K.Sammi Reddy. 2001. Effect of integrated use of fertilizer nitrogen and farmyard manure or green manure on transformations of $\mathrm{N}, \mathrm{K}$ and $\mathrm{S}$ and productivity of ricewheat system in Vertisol. J. Indian Soc. Soil Sci., 49: 430-434.

Osuna F.J., Canizalez, S.K., Dana, D. and Bonman, J.M. (1991). Nitrogen form and silicon nutrition effects on resistance to blast disease of rice. Plant and Soil, 135, 223-231.

Owino, C. and Gascho, G. J. (2004). Effect of Silicon on Low $\mathrm{pH}$ on Soil Phosphorus Sorption and Uptake and Growth of Maize. Communications in Soil Science and Plant Analysis, 35, 15-16.

Rahman, M. N., Islam, M. B., Sayem, S. M., Rahman, M. A. and Masud, M. M. (2007). Effect of different rates of sulphur on the yield and yield attributes of rice in old brahmaputra floodplain soil. Journal of Soil and Nature, 1 (1), 22-26.

Sauer, D. and Burghardt, W. (2000). Chemical process in soils on artificial materials: silicate dissolution, occurrence of amorphous silica and zeolites. In Procedings of the First International Conference on Soils of Urban, Industrial, Traffic and Mining areas, 12-18 July 2000. 339-346.

Shivay, Y.S. and Dinesh, K. (2009). Importance and management of 
silicon deficiency in rice. Indian Farming, 34-36.

Singh, K.K., Singh, S., Ragevendra, S., Yogeshvar, S. and Singh, C.S. (2006). Response of Nitrogen and silicon levels on growth, yield attribute and nutrient uptake of rice (Oryza sativa L.). Oryza, 43, 220-223.

Subramanian, S. and Gopalaswamy, A. (1991). Effect of moisture, organic matter, phosphate and silicate on availability on silicon and phosphorus in rice soils. Journal of Indian Society of Soil Science, 39, 99-103.

Sumida, H. (1992). Effect of nitrogen nutrition on silicon uptake by rice plant. Japanese Journal of Soil Science and Plant Nutrition, 63, 633638.

Tandon, H. L. S. and Tiwari, K. N. (2007). Fertiliser use in Indian Agriculture-An eventful half century. Better Crops, 1 (1), $3-5$.

Tiwari, K.N., Vandana, N. and Pathak, A. N. (1983). Effect of sulphur fertilization on yield response and sulphur and nitrogen composition of rice grown in the soils of Kanpur district. Indian Journal of Agricultural Sciences, 53, 812-819.
Tiwari, R. J. (1994). Response of gypsum on morphophysiochemical properties of cotton cultivars under salt affected vertisols of Madhya Pradesh. Crop Research, 7, 197-200.

Vaiyapuri, V. and M.V. Sriramachandrasekharan, (2001). Integrated use of green manure and sulphur on nutrient uptake and rice yield. J. Ecobiol., 13(3): 223-227.

Wang, L., Chen, Q., Cao, W., Wu, X., Li, M. and Zhang, F. (2001). Silicon induced cadmium tolerance of rice (Oryza sativa L.) seedlings. Pp 380-381. In: Datnoff, L.E., Snyder, G.H. and Korndorfer, G.H. (eds.) Silicon in Agriculture, Elsevier Science B.V.

Wani, M. A., Refique, M. M. and Talib, A. R.(2000). Effect of different levels of sulphur orn quality of rice. Advances in plant Sciences, 13(1), 55-57.

Wong You Cheong, Y., Heitz, A. and Dellville, J. (1973). The effect of silicon on sugar cane growth in pure nutrient solution. Journal of the Science of Food and Agriculture, 24, 113-119.

Zhu, H. J. (1985). Rice soil. Agricultural Publishing Press.

\section{How to cite this article:}

Vimal N. Patel, K.C. Patel and Chaudhary, K.V. 2019. Direct Effect of Silicon and Sulphur on Nutrient Content and Uptake of Rice Crop under Rice-Wheat Cropping Sequence. Int.J.Curr.Microbiol.App.Sci. 8(04): 625-634. doi: https://doi.org/10.20546/ijcmas.2019.804.068 